\title{
Mulberry and Peppermint Leaves Mixing Ratio Optimization for Skin Beauty
}

Shin-Young Lee ${ }^{1}$, Min-Ju Kim ${ }^{1}$, Ae-Jung Kim ${ }^{2 *}$

${ }^{1}$ Department of Alternative Medicine, Kyonggi University, Seoul, Korea

${ }^{2}$ Major of Beauty Wellness, The Graduate School of Alternative Medicine, Kyonggi University, Seoul, Korea

\author{
*Corresponding author: Ae-Jung Kim, Major \\ of Beauty Wellness, The Graduate School \\ of Alternative Medicine, Kyonggi University, \\ 24, Kyonggidae-ro-9 gil, Seodaemun-gu, \\ Seoul 03752 Korea \\ Tel.: +82 23905044 \\ Fax: +82 23905078 \\ Email: aj5249@naver.com
}

\section{Received July 18, 2021}

Revised July 24, 2021

Accepted September 2, 2021

Published September 30, 2021

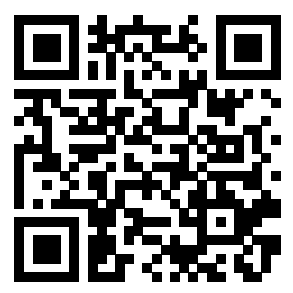

\begin{abstract}
Purpose: This study aims to determine the optimal mixing ratio of mulberry and peppermint leaves and evaluates their biological activities to identify whether the estimated ratio is suitable for use in inner beauty and cosmetic ingredients. Methods: Total polyphenol and flavonoid contents, 1,1-diphenyl-2-picrylhydrazyl (DPPH) and 2,2'-azino-bis-3-ethylbenzothiazoline-6-sulfonic acid (ABTS) radical scavenging activities, and tyrosinase and elastase inhibition activities were measured to optimize the mixing ratio of mulberry and peppermint leaves. Results: The mixture of mulberry and peppermint leaves showed a total polyphenol content of up to $46.58 \mathrm{mg} \mathrm{TAE} / \mathrm{g}$, a total flavonoid content of up to $45.54 \mathrm{mg}$ QE/g, and DPPH and ABTS radical scavenging activities of up to $74.18 \%$ and $40.60 \%$, respectively. Tyrosinase and elastase inhibition activities were up to $67.46 \%$ and $35.01 \%$, respectively. In the interest section, the maximum antioxidant and tyrosinase inhibitory activities were obtained at a mulberry:pepperint mixing ratio of 1.49:0.75 (g:g). In the experimental section, the maximum antioxidant and tyrosinase inhibitory activities were obtained at a mulberry:pepperint mixing ratio of 1.79:0.80 (g:g). Further, the maximum antioxidant and elastase inhibitory activities were obtained at a mulberry:pepperint mixing ratio of 1.11:0.75 (g:g). Conclusion: This study determined the superiority of the antioxidant activity, tyrosinase and elastase activity inhibition efficacies, and optimal mixing ratios of mulberry and peppermint leaves. Based on our findings, we believe that mulberry and peppermint leaves at an optimal mixing ratio will have considerable use as inner beauty and cosmetic ingredients.
\end{abstract}

Keywords: RSM, Mulberry leaf, Peppermint leaf, Tyrosinase inhibitory activity, Elastase inhibitory activity

\section{Introduction}

차의 기원은 신농씨(神農氏)가 백 가지 풀을 맛보면서 차가 해독에 이용되었다는 전설에서 시작된다. 중국의 전설적인 인물인 신농(神農) 이 쓴 약방문서인 신초본기(神草本紀)에는 차를 음용한 시기에서부터 약용으로 마시게 된 기록이 나온다(Cho \& Lee, 2011). 또한 조선 선 조 때 편찬된 의학서인 의림촬요에는 총 42 종의 차 활용 사례가 소개 되어 있는데, 차와 약재의 복합 처방, 외용제로 이용한 경우 등 머리를 맑게 하거나 차의 항균 및 살균능력을 이용한 처방들이 있다(Jo et al., 2019). 이렇게 고대사회로부터 오랜 세월동안 차를 계속해서 음용해 온
것은 차가 기호음료를 넘어 질병의 예방 효과를 갖는 건강음료로서 널 리 이용되어왔기 때문이다(Lee \& Jung, 2013).

최근 전 세계를 비롯하여 국내에서도 내면적 아름다움, 즉 신체 건강 유지 및 질병 등의 예방에 도움을 주는 미용기능식품인 이너뷰티(inner beauty) 식품에 대한 소비자의 관심과 요구가 증가하고 있다(Lee \& $\mathrm{Kem}, 2020)$. 일본의 경우 음식을 토대로 한 미용과 건강에 대한 관심 이 늘면서 미용기능식품 시장이 확대되고 있으며, 태국의 미용기능식품 제품의 경우 대부분 화이트닝과 안티에이징 기능성에 집중하고 있다. 국내에서는 천연재료를 사용하여 제품의 기능성을 부각하는 식품기업 들의 미용기능식품 관련 업계 진출이 활발히 이루어지고 있다(Shim \& 
Lee, 2019). 이러한 흐름에 따라 이너 뷰티 차에 대한 연구(Jung et al., 2019; Yoo et al., 2021)와 이너뷰티 소재로 활용가능한 추출물에 대한 연구(Lee \& Kem, 2020)등 천연재료를 이용한 미용기능식품에 대한 다 양한 연구들이 보고되어 있다. 그 중 뽕잎(Morus alba L.)은 약 2,200여 년 전부터 섭취되어온 것으로 신농본초경(神農本草經)에 약으로 좋다 고 기록되어 있으며, 동의보감(東醫寶鑑)에는 따뜻하고 독이 없으며 대· 소장을 이롭게 한다고 기록되어 있다(Lee et al., 2003). 또한 ascorbic acid, $\beta$-carotene, vitamin $\mathrm{D}$ 와 $\mathrm{Ca}, \mathrm{Fe}, \mathrm{Mg}$ 등의 무기질과 유기산, kaempferol, morusin, rutin 등의 플라보노이드와 같은 다양한 기능성 성분을 함유하고 있다(Gryn-Rynko et al., 2016). 이러한 뽕잎의 추출 물은 항산화 및 미백 활성이 있고(Gug, 2012), 뽕잎 분말을 이용한 천 연 팩과 비누가 미백 및 모공 축소 효과를 가진다(Song et al., 2012). 최 종당화산물을 유발한 흰쥐에게 뽕잎 추출물을 경구 투여한 결과 피부조 직에서 최종당화산물 바이오마커인 $\mathrm{CML}, \mathrm{CEL}, \mathrm{RAGE}$ 단백질 발현을 효과적으로 억제하였고, 피부 주름을 유발하는 효소인 MMP-1을 감소 시켜 콜라겐 감소를 억제하여 주름 개선에도 효과가 있음을 알 수 있었 다(Lee et al., 2017).

페퍼민트(Mentha Piperita L.)는 스피아민트(M. spicata L.)와 워터 민트(M. quatica L.)의 교배종인 다년생 초본으로 본래 유럽 토착 식 물이나 현재는 세계 여러 곳에서 재배되고 있다(McKay \& Blumberg, 2006). Menthol, menthone, isomenthone, menthofuran, neomenthol, limonene, cineole 등의 다양한 화합물과(Saleem et al., 2019), rutin, catechin hydrate, quercetin, chlorogenic acid 등의 기능성성분을 함유 하고 있다(Augšpole et al, , 2018). 이러한 기능성 성분을 함유한 페퍼민 트는 차 형태로 추출해도 항산화, 항알레르기, 항염증 등의 생리활성 효 과가 있었다(McKay \& Blumberg, 2006). 또한 페퍼민트잎을 수증기 증 류하여 얻어낸 에센셜오일은 여드름 피부에도 비교적 안전하게 사용할 수 있고(Lee \& Son, 2018), tyrosinase 저해 활성 역시 67\%의 높은 저 해 활성을 보여 미백 기능성도 확인되었다(Fiocco et al., 2011).
따라서 본 연구에서는 뽕잎과 페퍼민트잎의 항산화, 미백, 항주름 활 성을 평가하고, 활성을 최대화하는 최적 혼합비율을 구해 inner beauty 및 화장품 소재로서의 이용가치를 규명하고자 하였다.

\section{Methods}

\section{1. 실험재료}

본 실험에 사용된 뽕잎은 단야농장(Gimje, Korea)에서 2019년 6월 중순에 채취된 것을 구입하였으며, 페퍼민트잎은 대구허브농장(Daegu, Korea)에서 2019년 6월 중순에 채취된 것을 구입하여 로스팅 처리한 후 시료로 사용하였다.

\section{RSM을 이용한 뽕잎과 페퍼민트잎의 혼합비율 설정}

뽕잎과 페퍼민트잎의 최적 혼합 비율을 도출하기 위한 실험설계는 Design Expert 10 (Stat-Ease Inc., Minneapolis, USA) 프로그램을 사 용하였으며, 반응표면분석법 (response surface methodology, RSM)의 중심합성 계획법 설계에 따라 11 개의 실험점을 설정하였다.

독립변수는 뽕잎 $\left(\mathrm{X}_{1}\right)$, 페퍼민트잎 $\left(\mathrm{X}_{2}\right)$ 의 함량으로 설정하였고, 예비 실험을 거쳐 뽕잎 $\left(\mathrm{X}_{1}\right)$ 의 최소 및 최대 범위는 $0.5 \mathrm{~g}-1.5 \mathrm{~g}$ 으로 결정하 였으며, 페퍼민트잎 $\left(\mathrm{X}_{2}\right)$ 의 최소 및 최대 범위는 $0.25 \mathrm{~g}-0.75 \mathrm{~g}$ 으로 결 정하였다.

종속변수는 total polyphenol 함량, total flavonoid 함량, DPPH radical 소거능, ABTS radical 소거능, tyrosinase 저해 활성, elastase 저해 활성으로 설정하였다. 실험설계에 따른 실험점은 Table 1 에 제시 된 바와 같다.

\section{3. 추출 차 제조}

$\mathrm{RSM}$ 에 의해 설정된 11 개의 뽕잎과 페퍼민트잎 혼합 시료들을 혼

Table 1. Experimental design to optimize mixed ratio of mulberry $\left(X_{1}\right)$ and peppermint $\left(X_{2}\right)$ leaves using response surface method

\begin{tabular}{|c|c|c|}
\hline \multirow{2}{*}{ No. } & \multicolumn{2}{|c|}{ Actual values(ratio) } \\
\hline & $\mathrm{X}_{1}(\mathrm{~g})$ & $\mathrm{X}_{2}(\mathrm{~g})$ \\
\hline 1 & 1.71 & 0.50 \\
\hline 2 & 1.00 & 0.15 \\
\hline 3 & 1.00 & 0.50 \\
\hline 4 & 0.50 & 0.75 \\
\hline 5 & 0.29 & 0.50 \\
\hline 6 & 1.00 & 0.85 \\
\hline 7 & 0.50 & 0.25 \\
\hline 8 & 1.00 & 0.50 \\
\hline 9 & 1.50 & 0.25 \\
\hline 10 & 1.00 & 0.50 \\
\hline 11 & 1.50 & 0.75 \\
\hline
\end{tabular}


합량에 따라 $500 \mathrm{~mL}$ 용 컵에 $80^{\circ} \mathrm{C}$ 로 온도를 맞춘 물을 $200 \mathrm{~mL}$ 씩 넣 고 각각 $3 \mathrm{~min}$ 간 우려내어 생리활성 측정용 시료로 사용하였다.

\section{Total polyphenol 함량}

$\mathrm{RSM}$ 에 의해 설정된 11 개의 뽕잎과 페퍼민트잎 혼합 시료들의 total polyphenol 함량은 F-C 시약을 사용하는 Singleton \& Rossi (1965)의 방법을 변형하여 측정하였다. 시료 $350 \mu \mathrm{L}$ 에 $50 \%$ Folin-Denis 시약 $70 \mu \mathrm{L}$ 를 가하여 $3 \mathrm{~min}$ 간 정치한 후, $2 \%(\mathrm{w} / \mathrm{v}) \mathrm{Na}_{2} \mathrm{CO}_{3}$ 용액 $350 \mu \mathrm{L}$ 를 첨가하여 $1 \mathrm{~h}$ 반응시킨 후 ELISA microplate reader (Infinite M200 pro; Tecan, Switzerland)를 이용하여 $750 \mathrm{~nm}$ 에서 흡광도를 측정하 였다. Total polyphenol 함량은 tannic acid를 이용하여 작성한 표준곡 선으로부터 구하였다.

\section{Total flavonoid 함량}

$\mathrm{RSM}$ 에 의해 설정된 11 개의 뽕잎과 페퍼민트잎 혼합 시료들의 total flavonoid 함량은 Davis (1947)의 방법을 변형하여 측정하였다. 시료 $70 \mu \mathrm{L}$ 에 diethylene glycol $700 \mu \mathrm{L}$ 를 첨가하고 다시 $1 \mathrm{~N}-\mathrm{NaOH}$ 용액 $7 \mu \mathrm{L}$ 를 첨가한 후 $37^{\circ} \mathrm{C}$ 에서 $1 \mathrm{~h}$ 반응시킨 후 $\mathrm{ELISA}$ 를 이용하여 420 $\mathrm{nm}$ 에서 흡광도를 측정하였다. Total flavonoid 함량은 quercetin을 이 용하여 작성한 표준곡선으로부터 구하였다.

\section{DPPH radical 소거능}

$\mathrm{RSM}$ 에 의해 설정된 11 개의 뽕잎과 페퍼민트잎 혼합 시료들의 1 , 1-diphenyl-2-picrylhydrazyl (DPPH; Sigma-Aldrich, USA) radical 소거능은 Blois (1958)의 방법을 변형하여 측정하였다. 시료 $100 \mu \mathrm{L}$ 에 $1.5 \times 10^{-4} \mathrm{M} \mathrm{DPPH}$ 용액 $100 \mu \mathrm{L}$ 를 가하여 실온의 암실에서 $30 \mathrm{~min}$ 간 정치한 후 $\mathrm{ELISA}$ 를 이용하여 $517 \mathrm{~nm}$ 에서 흡광도를 측정하였다.

\section{ABTS radical 소거능}

$\mathrm{RSM}$ 에 의해 설정된 11 개의 뽕잎과 페퍼민트잎 혼합 시료들의 2,2'-azino-bis-3-ethylbenzothiazoline-6-sulfonic acid (ABTS; Sigma-Aldrich) radical 소거능은 Fellegrini et al. (1999)의 방법을 변형하여 측정하였다. ABTS 7.4 mM과 potassium persulphate 2.6 $\mathrm{mM}$ 을 같은 비율로 섞어 하루 동안 암소에 방치하여 $\mathrm{ABTS}$ 양이온을 형성시킨 후 $732 \mathrm{~nm}$ 에서 흡광도 값이 $0.70 \pm 0.02$ 가 되도록 $1 \times \mathrm{PBS}$ 로 희석하였다. 희석된 $\mathrm{ABTS}$ 용액 $190 \mu \mathrm{L}$ 에 추출물 시료 $10 \mu \mathrm{L}$ 를 가 하여 $10 \mathrm{~min}$ 간 정치한 후 ELISA를 이용하여 $732 \mathrm{~nm}$ 에서 흡광도를 측정하였다.

\section{Tyrosinase 저해 활성}

$\mathrm{RSM}$ 에 의해 설정된 11 개의 뽕잎과 페퍼민트잎 혼합 시료들의 tyrosinase 저해활성은 Ishihara et al. (1991)의 방법을 변형하여 측 정하였다. 시료의 tyrosinase 저해 활성은 tyrosinase 효소작용에 의한 L-tyrosine의 산화 정도를 측정하는 방법으로 실시하였다. $100 \mathrm{mM}$ 인산완충용액(pH 6.8) $80 \mu \mathrm{L}$ 에 시료 $80 \mu \mathrm{L}$ 와 mushroom tyrosinase (300 unit/mL) $20 \mu \mathrm{L}$ 을 첨가하여 $37^{\circ} \mathrm{C}$ 에서 $15 \mathrm{~min}$ 간 preheating 시 킨 후, L-tyrosine을 녹인 기질액 $(10 \mathrm{mM}) 20 \mu \mathrm{L}$ 를 넣어 $37^{\circ} \mathrm{C}$ 에서 25 $\min$ 간 반응시켜 생성된 DOPA chrome을 ELISA를 이용하여 $475 \mathrm{~nm}$ 에서 흡광도를 측정하였다.

\section{Elastase 저해 활성}

$\mathrm{RSM}$ 에 의해 설정된 11 개의 뽕잎과 페퍼민트잎 혼합 시료들의 elastase 저해 활성은 Kraunsoe et al. (1996)의 방법을 변형하여 측 정하였다. $200 \mathrm{mM}$ Tris-HCl buffer (pH 8.0) $30 \mu \mathrm{L}$ 에 시료 100 $\mu \mathrm{L}$ 및 Procine Pancreatic Elastase (PPE) $40 \mu \mathrm{L}$ 를 첨가하여 15분

Table 2. Antioxidant content of mulberry $\left(X_{1}\right)$ and peppermint $\left(X_{2}\right)$ leaves mixture using response surface design

\begin{tabular}{lllcc}
\hline No. & $\mathrm{X}_{1}(\mathrm{~g})$ & $\mathrm{X}_{2}(\mathrm{~g})$ & $\begin{array}{c}\text { Total polyphenol content } \\
\left(\mathrm{mg} \mathrm{TAE}^{2} / \mathrm{g}\right)\end{array}$ & $\begin{array}{c}\text { Total flavonoid content } \\
\left(\mathrm{mg} \mathrm{QE}^{3)} / \mathrm{g}\right)\end{array}$ \\
1 & $1.71^{1)}$ & 0.50 & 34.92 & 37.58 \\
2 & 1.00 & 0.15 & 21.40 & 23.29 \\
3 & 1.00 & 0.50 & 34.94 & 39.50 \\
4 & 0.50 & 0.75 & 46.48 & 41.58 \\
5 & 0.29 & 0.50 & 37.38 & 24.46 \\
6 & 1.00 & 0.85 & 46.58 & 38.29 \\
7 & 0.50 & 0.25 & 23.71 & 25.00 \\
9 & 1.00 & 0.50 & 35.37 & 39.01 \\
11 & 1.50 & 0.25 & 26.91 & 37.39 \\
\hline
\end{tabular}

${ }^{1)}$ Each of the 11 mixture samples were brewed in $200 \mathrm{~mL}$ of water at $80^{\circ} \mathrm{C}$ for $3 \mathrm{~min}$.

${ }^{2)} \mathrm{TAE}$, tannic acid equivalent.

${ }^{3)} \mathrm{QE}$, quercetin acid equivalent. 
간 preheating 시킨 후, N-Succinyl-Ala-Ala-Ala-p-nitroanilide $5 \mathrm{mg}$ 에 Tris-HCl buffer $1 \mathrm{~mL}$ 를 넣어 용해한 기질액 $30 \mu \mathrm{L}$ 를 첨가 하여 $25^{\circ} \mathrm{C}$ 에서 $25 \mathrm{~min}$ 간 반응 시킨 후 ELISA를 이용하여 $410 \mathrm{~nm}$ 에서 흡광도를 측정하였다.

\section{0. 통계처리}

실험 자료 분석과 최적화는 Design Expert 10 (Stat-Ease Inc., USA)을 이용하였고, 이외 모든 자료는 SPSS statistics 24 (SPSS Institute, USA)을 이용하여 표준편차와 평균을 구하여 통계 분석을 실시하였다.

독립변수 요인이 3개 이상인 경우에 one-way ANOVA를 실시하 였으며, Duncan's multiple range test로 각 시료 평균 차이에 대한 사후 검정을 유의 수준 $5 \%$ 에서 실시하였다.

\section{Results and Discussion}

\section{1. 뽕잎과 페퍼민트잎 혼합시료의 생리활성 및 회귀분석}

1) 항산화 성분 함량

폴리페놀은 식물이 다른 유기체로부터 자신을 보호하기 위해 생 산하는 2차 대사물이다. phenolic acids, flavonoids, stilbenes, polymeric proanthocyanidins 등을 포함하는 식이성 페놀 화합물 은 천연 항산화 물질 및 화학적 보호 물질 중의 하나이다(Shahidi \& Peng, 2018).

본 연구에서는 뽕잎 $\left(\mathrm{X}_{1}\right)$ 과 페퍼민트잎 $\left(\mathrm{X}_{2}\right)$ 을 독립변수로 하여 $\mathrm{RSM}$ 에 의해 설계된 11 개의 혼합 시료들의 total polyphenol 함량과 total flavonoid 함량을 분석하여 각각의 측정값은 Table 2에, 측정값 에 대한 회귀식은 Table 3에 제시하였다.

Table 3. Analysis of predicted model equation for antioxidant content of mulberry $\left(X_{1}\right)$ and peppermint $\left(X_{2}\right)$ leaves

\begin{tabular}{lccccccc}
\hline Response & Model & Mean & $\mathrm{R}^{21)}$ & F-value & $p$-value & Lack of fit & Polynomial equation $^{2)}$ \\
$\begin{array}{l}\text { Total polyphenol } \\
\text { content }\end{array}$ & 2FI & $34.99 \pm 1.03$ & 0.9896 & 220.97 & $<0.0001$ & 0.1425 & $+34.99-0.50 \mathrm{~A}+9.28 \mathrm{~B}-1.72 \mathrm{AB}$ \\
$\begin{array}{l}\text { Total flavonoid } \\
\text { content }\end{array}$ & Linear & $35.61 \pm 4.58$ & 0.7123 & 9.91 & 0.0068 & 0.0110 & $+35.61+4.36 \mathrm{~A}+5.74 \mathrm{~B}$ \\
\hline
\end{tabular}

1) $0 \leq R^{2} \leq 1$, indicates a regression line that can be used to fix the model.

${ }^{2)}$ Coded equation (the levels of the factor are coded as +1 and -1 ); $A$, mulberry leaf; B, peppermint leaf.

Table 4. Antioxidant activities of mulberry $\left(X_{1}\right)$ and peppermint $\left(X_{2}\right)$ leaves mixture by response surface design

\begin{tabular}{|c|c|c|c|c|}
\hline No. & $\mathrm{X}_{1}(\mathrm{~g})$ & $X_{2}(g)$ & $\begin{array}{c}\text { DPPH radical } \\
\text { scavenging activity (\%) }\end{array}$ & $\begin{array}{c}\text { ABTS radical } \\
\text { scavenging activity (\%) }\end{array}$ \\
\hline 1 & $1.71^{1)}$ & 0.50 & 62.00 & 30.99 \\
\hline 2 & 1.00 & 0.15 & 61.66 & 18.91 \\
\hline 3 & 1.00 & 0.50 & 63.78 & 30.03 \\
\hline 4 & 0.50 & 0.75 & 72.37 & 38.27 \\
\hline 5 & 0.29 & 0.50 & 67.29 & 31.63 \\
\hline 6 & 1.00 & 0.85 & 74.18 & 40.60 \\
\hline 7 & 0.50 & 0.25 & 64.50 & 21.15 \\
\hline 8 & 1.00 & 0.50 & 63.07 & 30.69 \\
\hline 9 & 1.50 & 0.25 & 59.50 & 25.36 \\
\hline 10 & 1.00 & 0.50 & 64.25 & 29.48 \\
\hline 11 & 1.50 & 0.75 & 73.49 & 38.01 \\
\hline
\end{tabular}

${ }^{1)}$ Each of the 11 mixture samples were brewed in $200 \mathrm{~mL}$ of water at $80^{\circ} \mathrm{C}$ for $3 \mathrm{~min}$.

DPPH, 2,2-diphenyl-1-picryl-hydrazyl-hydrate; ABTS, 2,2-azino-bis-(3-ethylbenzothiazothiazoline-6-sulfornic acid.

Table 5. Analysis of predicted model equation for antioxidant activities of mulberry $\left(X_{1}\right)$ and peppermint $\left(X_{2}\right)$ leaves

\begin{tabular}{|c|c|c|c|c|c|c|c|}
\hline Response & Model & Mean & $\mathrm{R}^{21)}$ & $F$-value & $p$-value & Lack of fit & Polynomial equation $^{2)}$ \\
\hline $\begin{array}{l}\text { DPPH radical } \\
\text { scavenging } \\
\text { activity }\end{array}$ & Quadratic & $66.01 \pm 1.33$ & 0.9594 & 35.41 & 0.0003 & 0.1286 & $\begin{array}{c}+64.42-1.42 \mathrm{~A}+4.95 \mathrm{~B}+1.53 \mathrm{AB} \\
+2.18 \mathrm{~B}^{2}\end{array}$ \\
\hline $\begin{array}{l}\text { ABTS radical } \\
\text { scavenging } \\
\text { activity }\end{array}$ & Linear & $30.47 \pm 1.22$ & 0.9747 & 153.81 & $<0.0001$ & 0.1738 & $+30.47+0.38 \mathrm{~A}+7.56 \mathrm{~B}$ \\
\hline
\end{tabular}


Table 2에 제시된 바와 같이 뽕잎과 페퍼민트잎 혼합 시료들의 total polyphenol 함량은 21.40-46.58 mg TAE/g의 범위로 나타났 다. 그 가운데 뽕잎 $1.00 \mathrm{~g}$ 과 페퍼민트잎 $0.85 \mathrm{~g}$ 을 혼합한 6 번 시료의 total polyphenol 함량이 $46.58 \mathrm{mg} \mathrm{TAE} / \mathrm{g}$ 으로 가장 높게 나타났다.

Table 3 에 제시된 바와 같이 total polyphenol 함량은 $2 \mathrm{FI}$ (two factor interaction) model이 선정되었다. 결과에 대한 회귀식의 $\mathrm{R}^{2}$ 값 은 $0.9896, p$ 값은 $<0.0001$ 로 유의하게 나타나 모델에 대한 높은 신뢰 도와 적합성을 보였다. 또한 Figure 1-a에 제시된 perturbation plot 에 따르면 페퍼민트잎(B)이 뽕잎(A)보다 total polyphenol 함량에 더 큰 영향을 준 것으로 나타났다.

Table 2에 제시된 바와 같이 뽕잎과 페퍼민트잎 혼합 시료들의 total flavonoid 함량은 23.29-45.54 mg QE/g의 범위로 나타났다. 그 가운데 뽕잎 $1.50 \mathrm{~g}$ 과 페퍼민트잎 $0.75 \mathrm{~g}$ 을 혼합한 11 번 시료의 total flavonoid 함량이 $45.54 \mathrm{mg} \mathrm{QE} / \mathrm{g}$ 으로 가장 높게 나타났다.

Table 3에 제시된 바와 같이 total flavonoid 함량은 linear model 이 선정되었다. 결과에 대한 회귀식의 $\mathrm{R}^{2}$ 값은 $0.712, p$ 값은 0.0068 로 유의하게 나타나 모델에 대한 높은 신뢰도와 적합성을 보였다. 또한 Figure 1-b에 제시된 perturbation plot에 따르면 뽕잎(A)과 페퍼민 트 잎(B) 모두 첨가량이 증가할수록 total flavonoid 함량이 높아지는 것으로 나타났다.
2) 항산화 활성

산소는 생존을 위해서는 필수적이지만 호흡과정 또는 환경요인 에 의하여 불안정하며, 반응성이 높은 라디칼인 활성산소종(reactive oxygen species, ROS)으로 전환된다(Kim et al, 2017). 체내 활성 산소의 축적은 심혈관계 질환, 신경계통 질환 등 많은 질병 및 노화 를 유발하는 주요 원인으로 간주되고 있다(Brieger et al., 2012).

본 연구에서는 뽕잎 $\left(\mathrm{X}_{1}\right)$ 과 페퍼민트잎 $\left(\mathrm{X}_{2}\right)$ 을 독립변수로 하여 $\mathrm{RSM}$ 에 의해 설계된 11 개의 혼합 시료들의 $\mathrm{DPPH}$ radical 소거능, ABTS radical 소거능을 분석하여 각각의 측정값은 Table 4에, 측정 값에 대한 회귀식은 Table 5 에 제시하였다.

Table 4에 제시된 바와 같이 뽕잎과 페퍼민트잎 혼합 시료들의 $\mathrm{DPPH}$ radical 소거능은 59.50-74.18\%의 범위로 나타났다. 그 가 운데 뽕잎 $1.00 \mathrm{~g}$ 과 페퍼민트잎 $0.85 \mathrm{~g}$ 을 혼합한 6 번 시료의 $\mathrm{DPPH}$ radical 소거능이 $74.18 \%$ 로 활성이 가장 높게 나타났다.

Table 5에 제시된 바와 같이 DPPH radical 소거능은 quadratic model이 선정되었다. 결과에 대한 회귀식의 $\mathrm{R}^{2}$ 값은 $0.9594, \mathrm{p}$ 값은 0.0003 으로 유의하게 나타나 모델에 대한 높은 신뢰도와 적합성을 보였다. 또한 Figure 1-c에 제시된 perturbation plot에 따르면 페 퍼민트잎(B)이 뽕잎(A)보다 DPPH radical 소거능에 더 큰 영향을 준 것으로 나타났다. 옥수수수염과 뽕잎 추출물을 혼합하여 발효한 음

Table 6. Tyrosinase and elastase inhibitory activities of mulberry $\left(X_{1}\right)$ and peppermint $\left(X_{2}\right)$ leaves using response surface design

\begin{tabular}{lllcc}
\hline No. & $\mathrm{X}_{1}(\mathrm{~g})$ & $\mathrm{X}_{2}(\mathrm{~g})$ & $\begin{array}{c}\text { Tyrosinase } \\
\text { Inhibitory activity (\%) }\end{array}$ & $\begin{array}{c}\text { Elastase } \\
\text { Inhibitory activity (\%) }\end{array}$ \\
1 & $1.71^{1)}$ & 0.50 & 55.49 & 24.15 \\
2 & 1.00 & 0.15 & 61.76 & 30.96 \\
3 & 1.00 & 0.50 & 53.71 & 26.60 \\
4 & 0.50 & 0.75 & 45.35 & 24.03 \\
5 & 0.29 & 0.50 & 51.73 & 15.62 \\
6 & 1.00 & 0.85 & 53.89 & 23.79 \\
7 & 0.50 & 0.25 & 61.80 & 24.05 \\
10 & 1.00 & 0.50 & 53.26 & 25.88 \\
11 & 1.50 & 0.25 & 67.46 & 35.01 \\
\hline
\end{tabular}

${ }^{1)}$ Each of the 11 mixture samples were brewed in $200 \mathrm{~mL}$ of water at $80^{\circ} \mathrm{C}$ for $3 \mathrm{~min}$.

Table 7. Analysis of predicted model equation for tyrosinase and elastase inhibitory activities of mulberry $\left(X_{1}\right)$ and peppermint $\left(\mathrm{X}_{2}\right)$ leaves

\begin{tabular}{|c|c|c|c|c|c|c|c|}
\hline Response & Model & Mean & $\mathrm{R}^{21)}$ & $F$-value & $p$-value & Lack of fit & Polynomial equation ${ }^{2)}$ \\
\hline $\begin{array}{l}\text { Tyrosinase } \\
\text { inhibitory } \\
\text { activity }\end{array}$ & Linear & $55.84 \pm 3.44$ & 0.7299 & 10.81 & 0.0053 & 0.0594 & $55.84+2.54 A-5.04 B$ \\
\hline $\begin{array}{l}\text { Elastase } \\
\text { inhibitory } \\
\text { activity }\end{array}$ & Quadratic & $25.60 \pm 2.08$ & 0.9071 & 9.76 & 0.0129 & 0.0609 & $\begin{array}{c}+26.56+2.91 \mathrm{~A}-2.61 \mathrm{~B}-2.68 \mathrm{AB}- \\
2.54 \mathrm{~A} 2+1.21^{2}\end{array}$ \\
\hline
\end{tabular}

1) $0 \leq R^{2} \leq 1$, indicates a regression line that can be used to fix the model.

2) Coded equation (the levels of the factor are coded as +1 and -1 ); $A$, mulberry leaf; $B$, peppermint leaf. 
A

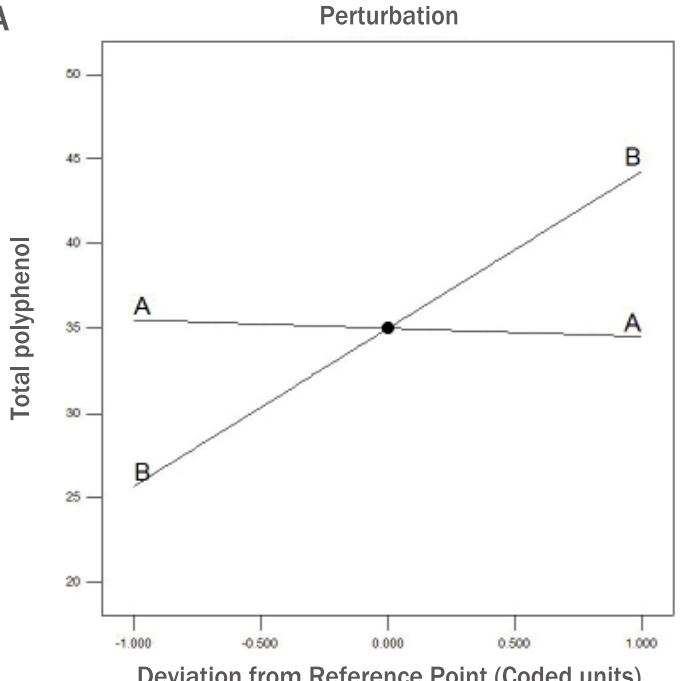

C

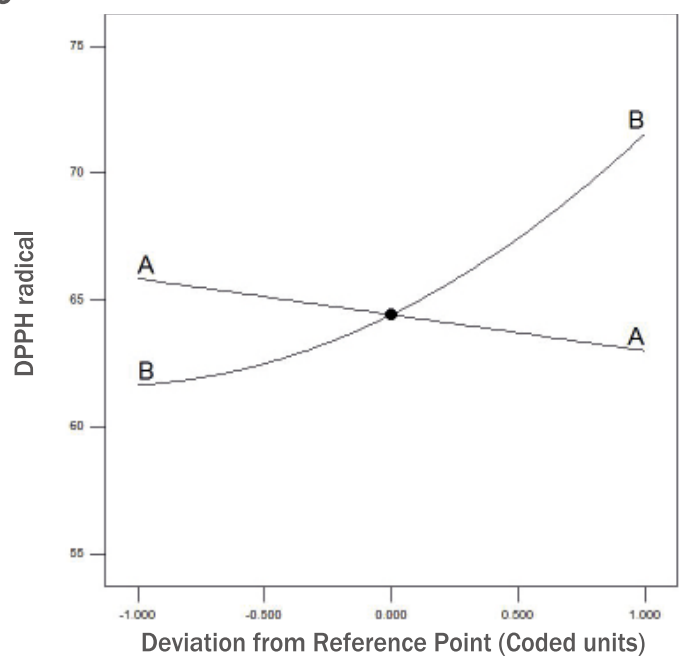

$\mathrm{E}$

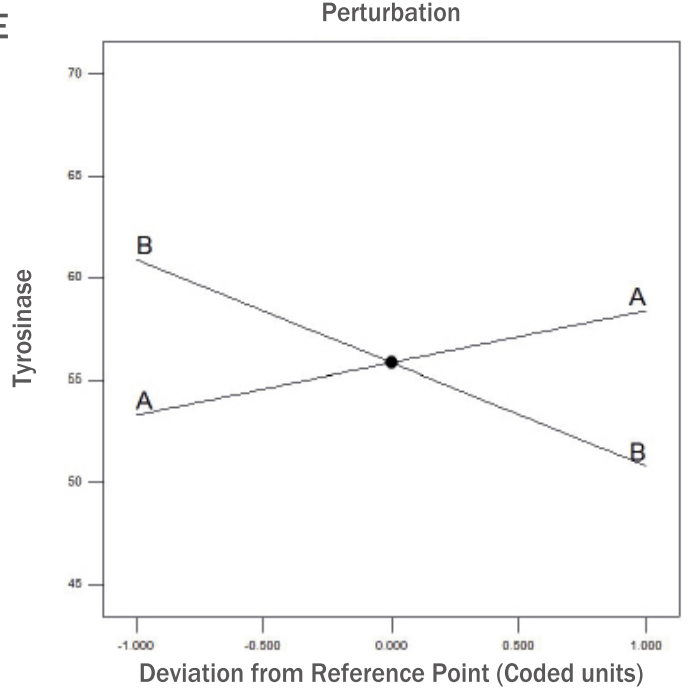

B

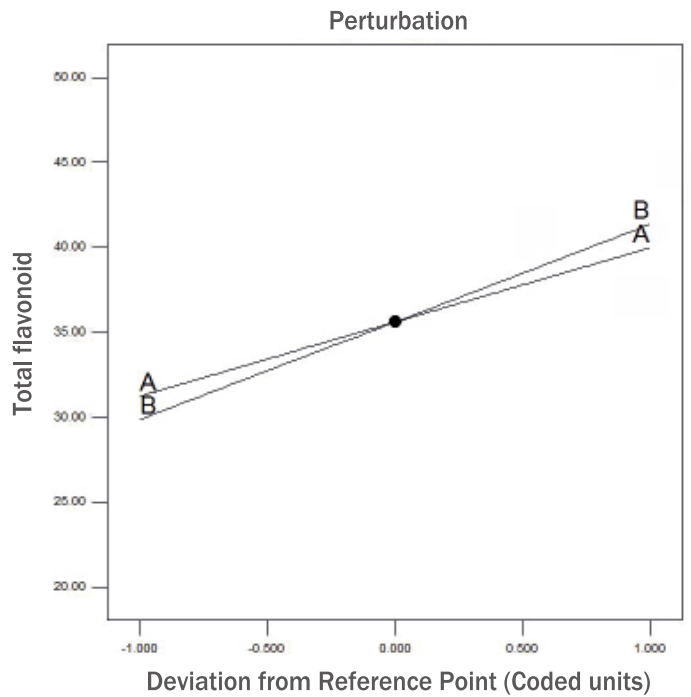

D

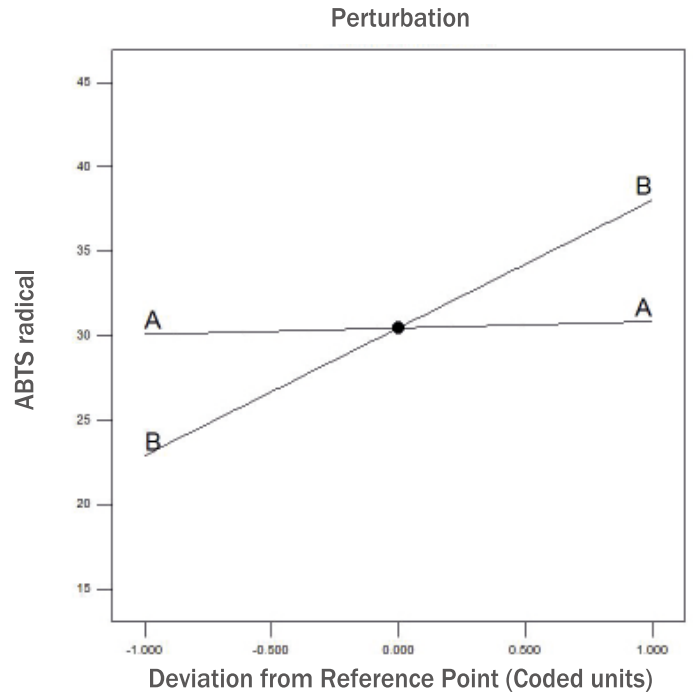

$\mathbf{F}$

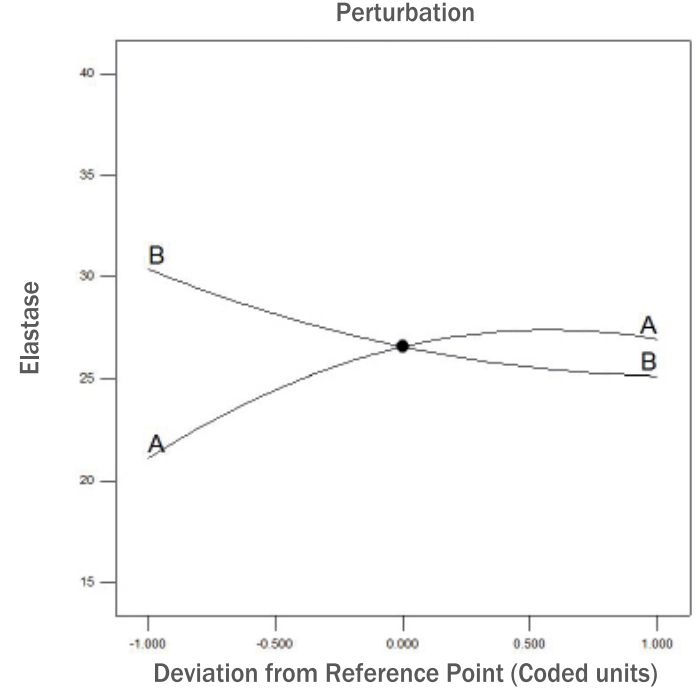

Figure 1. Perturbation plot of mulberry (A) and peppermint (B) leaves

(a) Total polyphenol content, (b) Total flavonoid content, (c) DPPH radical scavenging activity, (d) ABTS radical scavenging activity, (e) Tyrosinase inhibitory effect, and (f) Elastase inhibitory effect. 

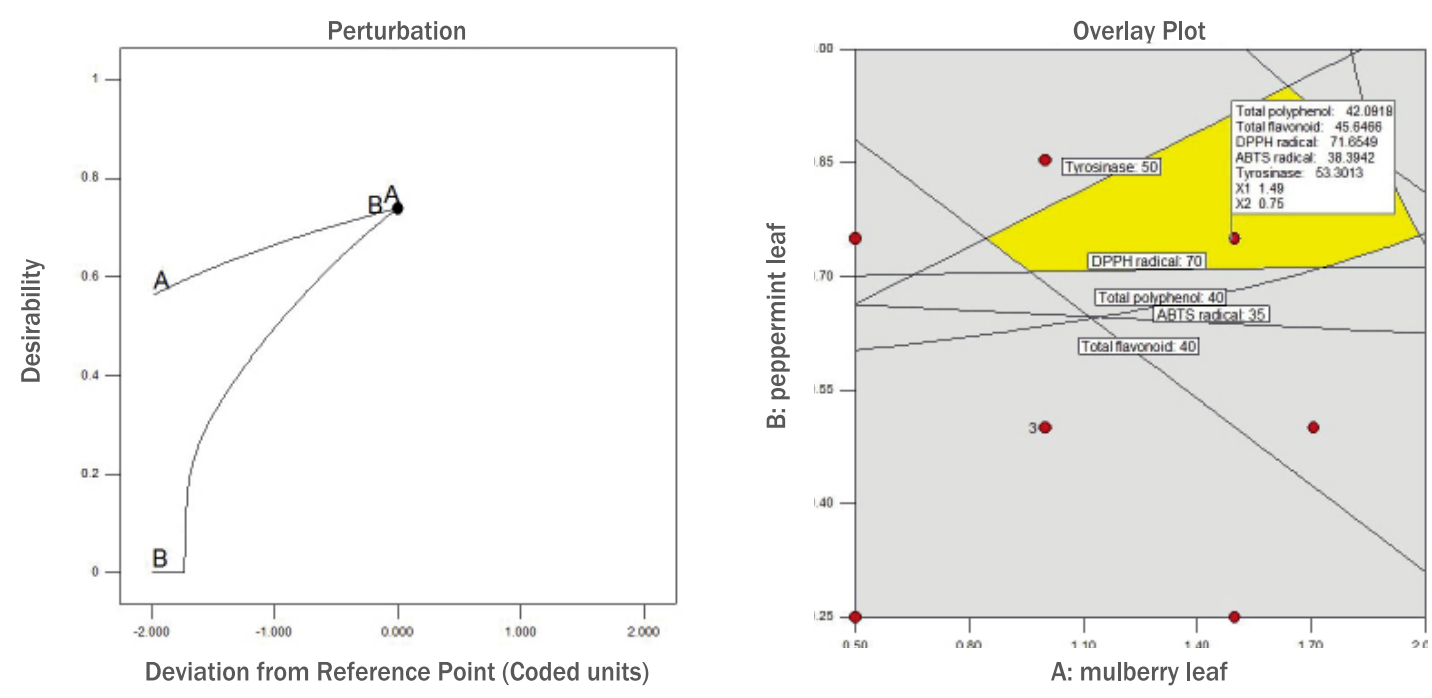

\section{Figure 2. Derived tyrosinase optimal blend ratio}

Perturbation and overlay plots for the effect of mulberry (A) and peppermint (B) leaves on antioxidant and tyrosinase inhibitory activities.

료의 항산화 활성을 측정한 결과 DPPH radical 소거능은 21.33$64.16 \%$ 의 범위로 나타났다. 또한 뽕잎 추출물의 첨가량이 증가할수 록 DPPH radical 소거능이 높아졌다(Oh \& Hong, 2021). 본 논문의 결과 옥수수수염과 뽕잎 추출물을 혼합하여 발효한 음료보다 DPPH radical 소거능이 높게 나타났으며, 앞선 연구와는 다르게 페퍼민트 잎이 결과에 더 큰 영향을 미쳤다. 이를 통해 뽕잎과 페퍼민트잎을 혼합한 것이 시너지 효과가 더 크게 나타났음을 미루어 짐작해 볼 수 있다.

Table 4에 제시된 바와 같이 뽕잎과 페퍼민트잎 혼합 시료들의 ABTS radical 소거능은 18.91-40.60\%의 범위로 나타났다. 그 가 운데 뽕잎 $1.00 \mathrm{~g}$ 과 페퍼민트잎 $0.85 \mathrm{~g}$ 을 혼합한 6 번 시료의 ABTS radical 소거능이 $40.60 \%$ 로 활성이 가장 높게 나타났다.

Table 5에 제시된 바와 같이 ABTS radical 소거능은 linear model이 선정되었다. 결과에 대한 회귀식의 $\mathrm{R}^{2}$ 값은 $0.9747, p$ 값은 〈0.0001로 유의하게 나타나 모델에 대한 높은 신뢰도와 적합성을 보 였다. 또한 Figure 1-d에 제시된 perturbation plot에 따르면 뽕잎 (A)과 페퍼민트잎(B) 모두 첨가량이 증가할수록 ABTS radical 소거 능이 높아지는 것으로 나타났다. 특히 ABTS radical 소거능과 total polyphenol 함량 모두에서 뽕잎 $1.00 \mathrm{~g}$ 과 페퍼민트잎 $0.85 \mathrm{~g}$ 을 혼합 한 6 번 시료의 활성이 가장 높게 나타났는데, 이는 total polyphenol 함량과 ABTS radical 소거능 사이에 높은 상관성이 있음을 보고한 연구 결과(Ham et al., 2015)와 일치한다.

\section{2. 뽕잎과 페퍼민트잎 혼합시료의 미백과 항주름활성 및 회귀분석}

1) Tyrosinase 저해 활성

멜라닌은 모발, 눈, 피부 등의 색을 담당하는 화합물로 tyrosinase
와 다른 tyrosinase 관련 단백질에 의해 촉매 되는 복잡한 과정을 통 해 합성된다(Niu \& Aisa, 2017). 따라서 멜라닌 생성의 주요 효소인 tyrosinase의 활성을 저해함으로써 멜라닌 생성을 억제시켜 미백 효 과를 유도할 수 있다(Jung et al, , 2009).

본 연구에서는 뽕잎 $\left(\mathrm{X}_{1}\right)$ 과 페퍼민트잎 $\left(\mathrm{X}_{2}\right)$ 을 독립변수로 하여 $\mathrm{RSM}$ 에 의해 설계된 11 개의 혼합 시료들의 tyrosinase 저해 활성을 분석하여 각각의 측정값은 Table 6에, 측정값에 대한 회귀식은 Table 7에 제시하였다.

Table 6에 제시된 바와 같이 뽕잎과 페퍼민트잎 혼합 시료의 tyrosinase 저해 활성은 45.35-67.46\% 범위로 나타났다. 그 가운데 뽕잎 $1.50 \mathrm{~g}$, 페퍼민트잎 $0.25 \mathrm{~g}$ 을 혼합한 9 번 시료의 tyrosinase 저 해 활성이 $67.46 \%$ 로 가장 높게 나타났다.

Table 7에 제시된 바와 같이 tyrosinase 저해 활성은 linear model 이 선정되었다. 결과에 대한 회귀식의 $\mathrm{R}^{2}$ 값은 $0.7299, p$ 값은 0.0053 으로 유의하게 나타나 모델에 대한 신뢰도와 적합성을 보였다. 또한 Figure 1-e에 제시된 perturbation plot에 따르면 뽕잎(A)이 페퍼민 트잎(B)보다 tyrosinase 저해 활성에 더 큰 영향을 준 것으로 나타났 다. Ju et al. (2009)의 연구에서 뽕잎의 tyrosinase 저해 활성을 측 정하였는데 물 추출물이 $20.74 \%$ 의 저해 활성이 나타났다. $\mathrm{Yi} \& \mathrm{Bu}$ (2017)의 연구에서는 $0.04 \%$ 의 농도의 페퍼민트 에센셜오일을 시료 로 하여 $\mathrm{B} 16 \mathrm{~F} 10$ 멜라노마 세포의 총 멜라닌 생성양 저해 활성을 측 정하였는데 $26.9 \pm 3.5 \%$ 의 저해 활성이 나타났다.

본 연구에서 뽕잎과 페퍼민트잎 혼합 시료들의 tyrosinase 저해 활성은 45.35-67.46\% 범위로 나타났다. 용매나 시료, 실험방법 간 에 차이는 있을 수 있지만 뽕잎과 페퍼민트를 각각 단일로 사용한 선 행연구들보다 비교적 더 높은 tyrosinase 저해 활성이 나타난 것으로 

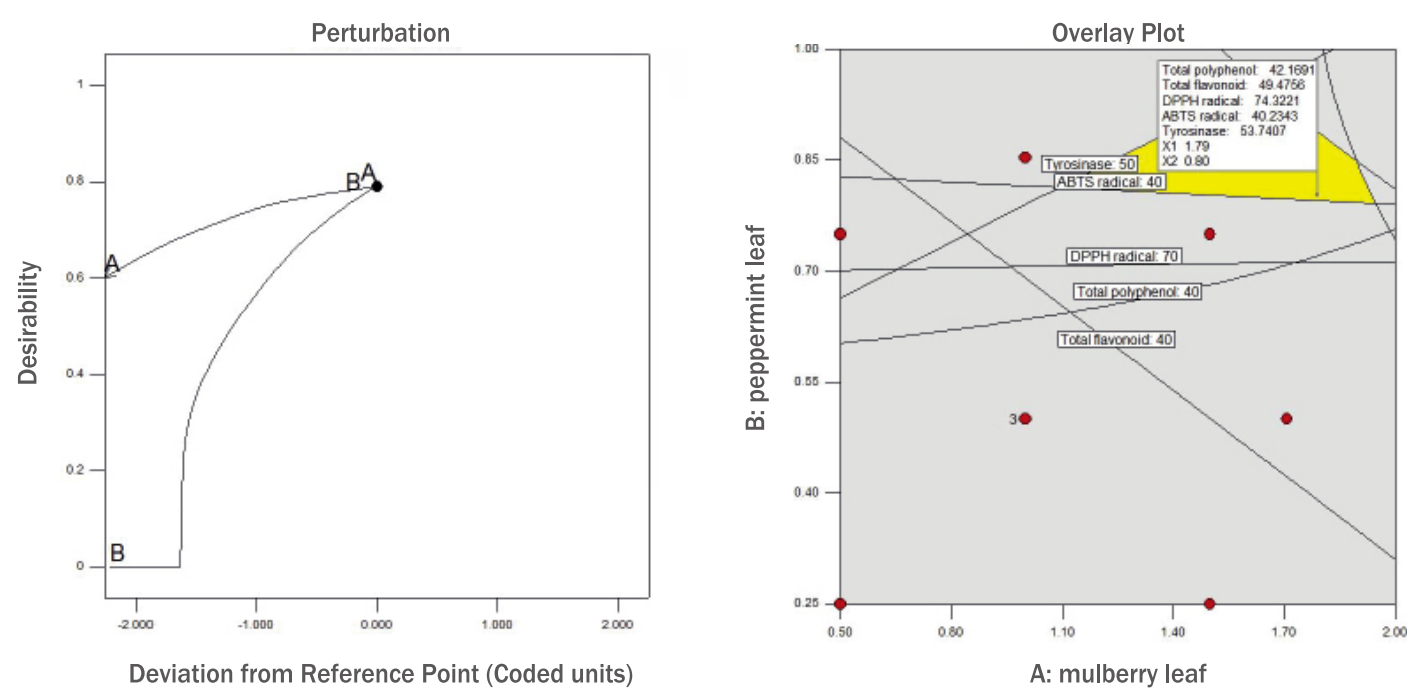

Figure 3. Derived extended tyrosinase optimal mixing ratio.

Perturbation and overlay plots of the effects of antioxidants and tyrosinase inhibition activities that extend the additives of mulberry (A) and peppermint (B) leaves into the experimental section.
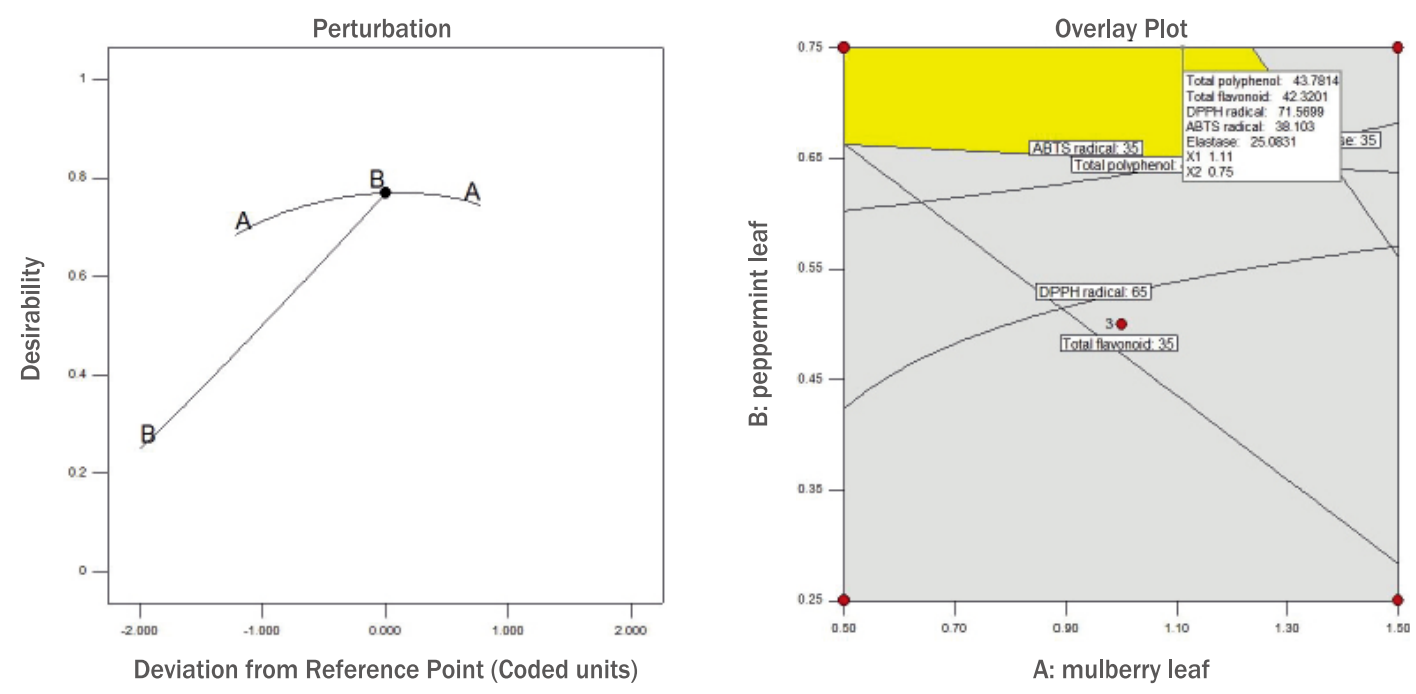

Figure 4. Derived elastase optimal blend ratio.

Perturbation and overlay plots for the effect of mulberry (A) and peppermint (B) leaves on antioxidant and elastase inhibitory activities.

미루어 볼 때 두 시료 간에 시너지 효과가 있음을 알 수 있다.

\section{2) Elastase 저해 활성}

엘라스틴은 대동맥, 폐, 연골, 인대, 피부 등 많은 세포조직의 탄 력과 복원력을 담당하며 단백질 분해에 상당한 저항력을 가지고 있 다. 그러나 elastase에 지속적으로 노출되면 탄성 섬유가 손상을 입 게 되고(Schmelzer et al, 2012), 이러한 손상이나 감소는 주름생성
및 탄력 저하 등 피부노화를 촉진시킨다. Elastase의 활성을 저해함 으로써 엘라스틴 분해를 억제해 피부주름 및 노화를 개선하는 효과 를 기대할 수 있다 (Song et al., 2017).

본 연구에서는 뽕잎 $\left(\mathrm{X}_{1}\right)$ 과 페퍼민트잎 $\left(\mathrm{X}_{2}\right)$ 을 독립변수로 하여 $\mathrm{RSM}$ 에 의해 설계된 11 개의 혼합 시료들의 elastase 저해 활성을 분 석하여 각각의 측정값은 Table 6에, 측정값에 대한 회귀식은 Table 7 에 제시하였다.

Table 6에 제시된 바와 같이 뽕잎과 페퍼민트잎 혼합 시료들의 
elastase 저해 활성은 15.62-35.01\% 범위로 나타났다. 그 가운데 뽕잎 $1.50 \mathrm{~g}$, 페퍼민트잎 $0.25 \mathrm{~g}$ 을 혼합한 9 번 시료의 elastase 저해 활성이 $35.01 \%$ 로 가장 높게 나타났다.

Table 7에 제시된 바와 같이 elastase 저해 활성은 quadratic model이 선정되었다. 결과에 대한 회귀식의 $\mathrm{R}^{2}$ 값은 $0.9071, p$ 값은 0.0129 로 유의하게 나타나 모델에 대한 높은 신뢰도와 적합성을 보 였다. 또한 Figure 1-f에 제시된 perturbation plot에 따르면 뽕잎 (A)이 페퍼민트잎(B)보다 elastase 저해 활성에 더 큰 영향을 준 것 으로 나타났다. 용매별 elastase 실험 결과 증류수 추출 뽕잎은 $19 \%$, $70 \%$ 에탄올 추출 뽕잎은 $6 \%, 70 \%$ 메탄올 추출 뽕잎은 $10.6 \%$ 로 증 류수로 추출한 뽕잎의 elastase 저해 활성이 가장 높았다(Kwak et al., 2005). Chiocchio et al. (2018)에서는 아유르베다에서 전통 적으로 쓰이는 100 가지 식물을 메탄올 추출하여 $50 \mu \mathrm{g} / \mathrm{mL}$ 농도에 서 elastase 저해 활성을 측정하였는데, 그 중 페퍼민트와 같은 꿀 풀과(Lamiaceae)인 쓴박하(Marrubium vulgare L.)와 은반백리향 (Thymus vulgaris L.)은 16\%, 프렌치라벤더(Lavandula stoechas L.)는 15\%, 로즈마리(Rosmarinus officinalis L.)는 26\%로 15-26\% 범위의 저해 활성을 보였다. 본 연구에서 뽕잎과 페퍼민트잎 혼합 시 료들의 elastase 저해 활성은 15.62-35.01\% 범위로 나타났다. 뽕잎 과 페퍼민트잎 혼합 시료가 단독 시료보다 더 높은 elastase 저해 활 성이 나타나 뽕잎과 페퍼민트잎 두 시료 간의 시너지 효과가 있음을 알 수 있다.

\section{3. 항산화와 미백활성을 위한 뽕잎과 페퍼민트잎의 혼합비율 최적화}

항산화 활성과 tyrosinase 저해 활성이 최대로 발현되는 뽕잎 과 페퍼민트잎의 최적 혼합비율을 구하기 위해 종속변수로 total polyphenol 함량, total flavonoid 함량, DPPH radical 소거능, ABTS radical 소거능 및 tyrosinase 저해 활성을 선정하였다.

뽕잎과 페퍼민트잎의 최소 및 최대 범위는 각각 $0.50 \mathrm{~g}-1.50 \mathrm{~g}$ 과 $0.25 \mathrm{~g}-0.75 \mathrm{~g}$ 으로 설정하였다. 항산화 활성과 tyrosinase 저해 활 성이 최대로 발현되는 최적 혼합 비율을 예측하고자 하였으며 최고 의 desirability를 나타낸 최적점을 선택한 후 지점 예측을 통해 최적 혼합 비율을 산출하였다.

Figure 2에 제시된 perturbation plot을 보면 뽕잎(A)과 페퍼민트 잎(B) 모두 첨가량이 증가할수록 항산화와 미백 활성을 높이는 요인 으로 작용하였다.

Figure 2에 제시된 overlay plot을 보면 항산화 활성과 tyrosinase 저해 활성이 최대로 발현된 뽕잎과 페퍼민트잎의 혼합 비율은 뽕잎 (A)이 $1.49 \mathrm{~g}$, 페퍼민트잎(B)이 $0.75 \mathrm{~g}$ 이다. 이때 total polyphenol 함량은 $42.09 \mathrm{mg} \mathrm{TAE} / \mathrm{g}$, total flavonoid 함량은 $45.65 \mathrm{mg} \mathrm{QE} / \mathrm{g}$, $\mathrm{DPPH}$ radical 소거능은 $71.65 \%$, ABTS radical 소거능은 $38.39 \%$, tyrosinase 저해 활성은 $53.30 \%$ 로 예측되었다.

위의 최적비율은 페퍼민트잎이 흥미구간 내 최고점 $(0.75 \mathrm{~g})$ 이라, 뽕잎과 페퍼민트잎의 함량 구간을 실험범위내로 확장하여 항산화 활
성과 tyrosinase 저해 활성이 최대로 발현되는 최적 혼합 비율을 추 가로 예측해보았다.

Figure 3에 제시된 perturbation plot을 보면 뽕잎 $(\mathrm{A})$ 은 실험구간 내에서 첨가량이 증가할수록 항산화 활성과 tyrosinase 저해 활성을 높이는 요인으로 작용하였다. 페퍼민트잎(B)은 흥미구간 내에서는 첨가량이 증가할수록 항산화와 tyrosinase 저해 활성을 높이는 요인 으로 작용하였으나, 실험구간 내로 확장한 경우 $(0.80 \mathrm{~g}$ 이상 $)$ 첨가량 이 증가할수록 항산화와 tyrosinase 저해 활성을 떨어뜨리는 요인으 로 작용하였다.

Figure 3 에 제시된 overlay plot을 보면 실험구간 내에서 항산화 와 tyrosinase 저해 활성이 최대로 발현된 뽕잎과 페퍼민트잎의 혼합 비율은 뽕잎(A)이 $1.79 \mathrm{~g}$, 페퍼민트잎(B)이 $0.80 \mathrm{~g}$ 이다. 이때 total polyphenol 함량은 $42.17 \mathrm{mg} \mathrm{TAE} / \mathrm{g}$, total flavonoid 함량은 49.48 $\mathrm{mg} \mathrm{QE} / \mathrm{g}$, DPPH radical 소거능은 $74.32 \%$, ABTS radical 소거능 은 $40.23 \%$, tyrosinase 저해 활성은 $53.74 \%$ 로 예측되었다.

\section{4. 항산화와 항주름 활성을 위한 뽕잎과 페퍼민트잎의 혼합비율 최적화}

항산화 활성과 elastase 저해 활성이 최대로 발현되는 뽕잎과 페퍼 민트잎의 최적 혼합비율을 구하기 위해 종속변수로 total polyphenol 함량, total flavonoid 함량, DPPH radical 소거능, ABTS radical 소 거능 및 elastase 저해 활성을 선정하였다.

뽕잎과 페퍼민트잎의 최소 및 최대 범위는 각각 $0.50 \mathrm{~g}-1.50 \mathrm{~g}$ 과 $0.25 \mathrm{~g}-0.75 \mathrm{~g}$ 으로 설정하였다. 항산화 활성과 elastase 저해 활성 이 최대로 발현되는 최적 혼합 비율을 예측하고자 하였으며 최고의 desirability를 나타낸 최적점을 선택한 후 지점 예측을 통해 최적 혼 합 비율을 산출하였다.

Figure 4에 제시된 perturbation plot을 보면 뽕잎 $(\mathrm{A})$ 은 첨가량이 증가할수록 항산화와 elastase 저해 활성을 높이는 요인으로 작용하 다가 첨가량이 $60 \%$ 이상이 되면 항산화와 elastase 저해 활성을 오 히려 떨어뜨리는 요인으로 작용하였다. 페퍼민트잎(B)은 첨가량이 증가할수록 항산화와 elastase 저해 활성을 높이는 요인으로 작용하 였다.

Figure 4에 제시된 overlay plot을 보면 항산화 활성과 elastase 저해 활성이 최대로 발현된 뽕잎과 페퍼민트잎의 혼합 비율은 뽕잎 (A)이 $1.11 \mathrm{~g}$, 페퍼민트잎(B)이 $0.75 \mathrm{~g}$ 이다. 이때 total polyphenol 함량은 $43.78 \mathrm{mg} \mathrm{TAE} / \mathrm{g}$, total flavonoid 함량은 $42.32 \mathrm{mg} \mathrm{QE} / \mathrm{g}$, DPPH radical 소거능은 $71.57 \%$, ABTS radical 소거능은 $38.10 \%$, elastase 저해 활성은 $25.08 \%$ 로 예측되었다.

\section{Conclusion}

본 연구는 뽕잎과 페퍼민트잎의 생리활성 평가를 실시하여 최적 
혼합비율을 찾고, 피부 미용을 위한 inner beauty 소재 및 화장품 소 재로의 이용가치를 규명하고자 하였다. 따라서 $\mathrm{RSM}$ 을 이용하여 11 개의 실험점을 설정한 후 항산화 성분 함량(total polyphenol 함량, total flavonoid 함량) 및 항산화 활성(DPPH radical 소거능, ABTS radical 소거능)을 분석하였다. 미백 활성을 알아보기 위해 tyrosinase 저해활성을 측정하였고, 항주름 활성을 알아보기 위해 elastase 저해 활성을 측정하여 분석하였다.

그 결과 뽕잎과 페퍼민트잎 혼합 시료의 total polyphenol 함량은 뽕잎 $1.00 \mathrm{~g}$ 과 페퍼민트잎 $0.85 \mathrm{~g}$ 을 혼합한 6 번 시료가 $46.58 \mathrm{mg}$ $\mathrm{TAE} / \mathrm{g}$ 으로 가장 높게 나타났다. Total flavonoid 함량은 뽕잎 1.50 $\mathrm{g}$ 과 페퍼민트잎 $0.75 \mathrm{~g}$ 을 혼합한 11 번 시료가 $45.54 \mathrm{mg} \mathrm{QE} / \mathrm{g}$ 으 로 가장 높게 나타났다. DPPH radical 소거능과 ABTS radical 소거 능은 뽕잎 $1.00 \mathrm{~g}$ 과 페퍼민트잎 $0.85 \mathrm{~g}$ 을 혼합한 6 번 시료가 각각 $74.18 \%, 40.60 \%$ 로 가장 높은 활성을 보였다. Tyrosinase 저해 활성 과 elastase 저해 활성은 뽕잎 $1.50 \mathrm{~g}$, 페퍼민트잎 $0.25 \mathrm{~g}$ 을 혼합한 9 번 시료가 각각 $67.46 \%, 35.01 \%$ 로 가장 높은 활성을 보였다.

항산화 활성과 tyrosinase 저해 활성이 최대로 발현된 뽕잎과 페 퍼민트잎의 혼합 비율은 뽕잎(A)이 $1.49 \mathrm{~g}$, 페퍼민트잎(B)이 0.75 $\mathrm{g}$ 이었다. 이때 total polyphenol 함량은 $42.09 \mathrm{mg} \mathrm{TAE} / \mathrm{g}$, total flavonoid 함량은 $45.65 \mathrm{mg} \mathrm{QE} / \mathrm{g}, \mathrm{DPPH}$ radical 소거능은 $71.65 \%$, ABTS radical 소거능은 $38.39 \%$, tyrosinase 저해 활성은 $53.30 \%$ 로 예측되었다.

뽕잎과 페퍼민트잎의 함량을 실험범위내로 확장한 후 항산화 활 성과 tyrosinase 저해 활성이 최대로 발현되는 최적 혼합 비율을 추 가로 예측한 결과 실험구간 내에서 항산화 활성과 tyrosinase 저해 활성이 최대로 발현된 뽕잎과 페퍼민트잎의 혼합 비율은 뽕잎(A)이 $1.79 \mathrm{~g}$, 페퍼민트잎(B)이 $0.80 \mathrm{~g}$ 이었다. 이때 total polyphenol 함 량은 $42.17 \mathrm{mg} \mathrm{TAE} / \mathrm{g}$, total flavonoid 함량은 $49.48 \mathrm{mg} \mathrm{QE} / \mathrm{g}$, $\mathrm{DPPH}$ radical 소거능은 $74.32 \%$, ABTS radical 소거능은 $40.23 \%$, tyrosinase 저해 활성은 $53.74 \%$ 로 예측되어 페퍼민트잎이 $0.80 \mathrm{~g}$ 첨 가되었을 경우, $0.75 \mathrm{~g}$ 첨가되었을 때 보다 tyrosinase 저해 활성이 $0.44 \%$ 더 높게 예측되는 것을 확인할 수 있었다.

항산화 활성과 elastase 저해 활성이 최대로 발현된 뽕잎과 페퍼민 트잎의 혼합 비율은 뽕잎(A)이 $1.11 \mathrm{~g}$, 페퍼민트잎(B)이 $0.75 \mathrm{~g}$ 이었 다. 이때 total polyphenol 함량은 $43.78 \mathrm{mg} \mathrm{TAE} / \mathrm{g}$, total flavonoid 함량은 $42.32 \mathrm{mg} \mathrm{QE} / \mathrm{g}, \mathrm{DPPH}$ radical 소거능은 $71.57 \%$, ABTS radical 소거능은 $38.10 \%$, elastase 저해 활성은 $25.08 \%$ 로 예측되었 다.

이상의 결과, 뽕잎과 페퍼민트잎의 항산화 활성, tyrosinase 및 elastase 활성 억제 효능의 우수성을 규명하고, 최적 혼합 비율도 도 출할 수 있었다. 뽕잎 $1.79 \mathrm{~g}$ 과 페퍼민트잎 $0.80 \mathrm{~g}$ 을 혼합하면 항산화 활성과 피부 미백에 도움이 되고, 뽕잎 $1.11 \mathrm{~g}$ 과 페퍼민트잎 $0.75 \mathrm{~g}$ 을 혼합하면 항산화 활성과 피부 주름 개선에 도움이 되는 inner beauty 소재 또는 화장품 소재로의 이용 가치가 높을 것으로 생각된다.
This work is part of the Shin-Young Lee's M.S. thesis at the Kyonggi University, Seoul, Korea.

\section{Author's contribution}

SYL as the first author, contributed to all aspects of analysis and experimental design, and wrote the manuscript. MJK as the second author, contributed to experimental design and manuscript. AJK as the third author, contributed to all the experimental design in detail and correcting the errors directly.

\section{Author details}

Shin-young Lee (Graduate student), Department of Alternative Medicine, Kyonggi University, 24, Kyonggidaero-9 gil, Seodaemun-gu, Seoul 03746, Korea; Min-ju Kim (Professor), Department of Alternative Medicine, Kyonggi University, 24, Kyonggidaero-9 gil, Seodaemun-gu, Seoul 03746, Korea; Ae-jung Kim (Professor), Major of Beauty Wellness, The Graduate School of Alternative Medicine, Kyonggi University, 24, Kyonggidaero-9 gil, Seodaemun-gu, Seoul 03752, Korea.

\section{References}

Augšpole I, Dūma M, Cinkmanis I, Ozola B. Herbal teas as a rich source of phenolic compounds. CHEMIJA, 29: 257262, 2018.

Blois MS. Antioxidant determinations by the use of a stable free radical. Nature, 181: 1199-1200, 1958.

Brieger K, Schiavone S, Miller Jr. FJ, Krause KH. Reactive oxygen species: from health to disease. Swiss Medical Weekly, 142: w13659, 2012.

Chiocchio I, Mandrone M, Sanna C, Maxia A, Tacchini M, Poli F. Screening of a hundred plant extracts as tyrosinase and elastase inhibitors, two enzymatic targets of cosmetic interest. Industrial Crops \& Products, 122: 498-505, 2018.

Cho KJ, Lee SO. Study on traditional medicinal-herb tea. Journal of the Korean Tea Society, 17: 1-7, 2011.

Davis WB. Determination of flavanones in Citrus fruits. Analytical Chemistry, 19: 476-478, 1947.

Fellegrini N, Ke R, Yang M, Rice-Evans C. Screening of dietary carotenoids and carotenoid-rich fruit extracts 
for antioxidant activities applying 2,2'-azinobis (3-ethylenebenzothiazoline-6-sulfonic acid radical cation decolorization assay. Methods in Enzymology, 299: 379389, 1999.

Fiocco D, Fiorentino D, Frabboni L, Benvenuti S, Orlandini G, Pellati F, Gallone A. Lavender and peppermint essential oils as effective mushroom tyrosinase inhibitors: a basic study. Flavour and Fragrance Journal, 26: 441-446, 2011.

Gryn-Rynko A, Bazylak G, Olszewska-Slonina D. New potential phytotherapeutics obtained from white mulberry (Morus alba L.) leaves. Biomedicine \& Pharmacotherapy, 84: 628-636, 2016.

Gug K. Physiological and whitening effects of Morus alba extracts. Journal of the Chosun Natural Science, 5: 46-52, 2012.

Ham HM, Woo KS, Lee BW, Park JY, Sim EY, Kim BJ, Lee CW, Kim SJ, Kim WH, Lee JS, et al. Antioxidant compounds and activities of methanolic extracts from oat cultivars. Journal of the Korean Society of Food Science and Nutrition, 44: 1660-1665, 2015.

Ishihara Y, Oka M, Tsunakawa M, Tomita K, Hatori M, Yamamoto H, Kamei H, Miyaki T, Konishi M, Oki T. Melanostatin, a new melanin synthesis inhibitor production, isolation, chemical properties, structure and biological activity. The Journal of Antibiotics, 44: 25-32, 1991.

Jo JK, Chun YS, Lee KN. A study on the efficacy of tea in the UiRimChualYo of the chosun dynasty. The journal of tea culture \& industry studies, 43: 51-74, 2019.

Ju MJ, Kwon JH, Kim HK. Physiological activities of mulberry leaf and fruit extracts with different extraction conditions. The Korean Society of Food Preservation, 16: 442-448, 2009.

Jung SH, Ku MJ, Moon HJ, Yu BC, Jeon MJ, Lee YH. Inhibitory effects of fucoidan on melanin synthesis and tyrosinase activity. Journal of Life Science, 19: 75-80, 2009.

Jung YH, Han JS, Kim AJ. Quality evaluation and antioxidant activity of inner beauty tea prepared from roasted lotus root and burdock. Asian journal of beauty and cosmetology, 17: 235-245, 2019.

Kim GY, Park IS, Kim SH. The effect of added shiitake mushroom on antioxidative activity of puffer fish stock. The Korean Journal of Food and Nutrition, 30: 742-748, 2017.
Kraunsoe JAE, Claridge TDW, Lowe G. Inhibition of human leukocyte and porcine pancreatic elastase by homologues of bovine pancreatic trypsin inhibitor. Biochemistry, 35: 9090-9096, 1996.

Kwak YJ, Lee DH, Kim NM, Lee JS. Screening and extraction condition of anti-skin aging elastase inhibitor from medicinal plants. Korean Journal of Medicinal Crop Science, 13: 213-216, 2005.

Lee AR, Kim SH, Kim SJ, Kim KJ, Kwon OJ, Choi JY, Roh SS. Anti-skin-aging effect of mori folium through decreased advanced glycation end product (AGEs). The Korea Journal of Herbology, 32: 7-12, 2017.

Lee JN, Kem YS. Availability of passiflora caerulea extract as inner beauty material. Journal of the Korean Applied Science and Technology, 37: 1180-1189, 2020.

Lee JY, Son HJ. Trends in the efficacy and safety of ingredients in acne skin treatments. Asian Journal of Beauty and Cosmetology, 16: 449-463, 2018.

Lee S, Jung J. Korean tea therapy in "The Annals of the Joseon Dynasty". Journal of Society of Preventive Korean Medicine, 17: 17-28, 2013.

Lee WC, Kim AJ, Kim SY. The study on the functional materials and effects of mulberry leaf. Food science and industry, 36: 2-14, 2003.

McKay D, Blumberg JB. A review of the bioactivity and potential health benefits of peppermint tea (Mentha piperita L). Phytotherapy Research, 20: 619-633, 2006.

Niu C, Aisa HA. Upregulation of melanogenesis and tyrosinase activity: potential agents for vitiligo. Molecules, 22: 1303, 2017.

Oh SW, Hong JH. Development of fermented beverage using corn silk and mulberry leaf extracts. The Korean Society of Food Preservation, 28: 199-208, 2021.

Saleem A, Durrani Al, Fatima BA, Irfan A, Noreen M, Kamran A, Duaa A. Preparation of marketable functional food to control hypertension using basil (ocimum basillium) and peppermint (mentha piperita). International Journal of Innovations in Science \& Technology, 1: 15-32, 2019.

Schmelzer CEH, Jung MC, Wohlrab J, Neubert RHH, Heinz A. Does human leukocyte elastase degrade intact skin elastin?. FEBS Journal, 279: 4191-4200, 2012.

Shahidi F, Peng H. Bioaccessibility and bioavailability of phenolic compounds. International Society for Nutraceuticals and Functional Foods, 4: 11-68, 2018. 
Shim BS, Lee BJ. Market trends for nutricosmetics. Korean Industrial Chemistry News, 22: 23-37, 2019.

Singleton VL, Rossi JA. Colorimetry of total phenolics with phosphomolybdic-phosphotungstic acid reagents. American Journal of Enology and Viticulture, 16: 144-158, 1965.

Song BJ, Cho JY, Ma SJ, Park KJ, Park HJ, Choi GC, Ha H, Na HS. Antioxidant, anti-tyrosinase, and anti-elastase activities of alternative tea materials (Mugwort, Bower Actinidia, Arrowroot) by harvest time and region: a comparative in vitro study. Journal of the Korean Tea Society, 23: 65-73, 2017.
Song HK, Kwon SY, Lim YS, Kim AJ. The amelioratory effect of natural cosmetic pack and natural soap containing mulberry leaf powder on the skin status of adult men. Asian Journal of Beauty and Cosmetology, 10: 911-919, 2012.

Yi MR, Bu HJ. Antioxidant, antimicrobial and melanogenesis inhibition effects of 35 species essential oil. Journal of The Korean Society of cosmetology, 23: 677-687, 2017.

Yoo IS, Park JM, Kim AJ. Evaluation of the physicochemical activities of frequently consumed edible flower teas in Korea. Asian Journal of Beauty and Cosmetology, 19: 289301, 2021. 


\section{국문초록}

\section{피부 미용을 위한 뽕잎과 페퍼민트잎의 혼합비율 최적화 연구}

이신영 ${ }^{1}$, 김민주 ${ }^{1}$, 김애정 ${ }^{2 *}$

${ }^{1}$ 경기대학교 대체의학과, 서울, 한국

${ }^{2}$ 경기대학교 대체의학대학원 뷰티웰니스전공, 서울, 한국

목적: 본 연구는 뽕잎과 페퍼민트잎의 생리활성 평가를 실시하여 최적 혼합비율을 찾고, 이를 통해 inner beauty 소재 및 화장품 소 재로의 이용가치를 규명하고자 하였다. 방법: 뽕잎과 페퍼민트잎의 혼합비율 최적화를 위해 뽕잎과 페퍼민트잎 혼합 시료의 total polyphenol 함량, total flavonoid 함량, DPPH radical 소거능, ABTS radical 소거능, tyrosinase 저해활성, elastase 저해활성을 측정 하였다. 결과: 뽕잎과 페퍼민트잎 혼합 시료의 total polyphenol 함량은 최대 $46.58 \mathrm{mg} \mathrm{TAE} / \mathrm{g}$, total flavonoid 함량은 최대 45.54 $\mathrm{mg} \mathrm{QE} / \mathrm{g}$, DPPH radical 소거능과 ABTS radical 소거능은 각각 최대 $74.18 \%, 40.60 \%$ 였다. Tyrosinase 저해 활성과 elastase 저 해 활성은 각각 최대 $67.46 \%, 35.01 \%$ 였다. 흥미구간 내 항산화 활성과 tyrosinase 저해 활성이 최대로 발현된 뽕잎과 페퍼민트잎 의 혼합 비율은 뽕잎이 $1.49 \mathrm{~g}$, 페퍼민트잎이 $0.75 \mathrm{~g}$ 이었다. 실험구간 내 항산화 활성과 tyrosinase 저해 활성이 최대로 발현된 뽕잎 과 페퍼민트잎의 혼합 비율은 뽕잎이 $1.79 \mathrm{~g}$, 페퍼민트잎이 $0.80 \mathrm{~g}$ 이었다. 항산화 활성과 elastase 저해 활성이 최대로 발현된 뽕잎 과 페퍼민트잎의 혼합 비율은 뽕잎이 $1.11 \mathrm{~g}$, 페퍼민트잎이 $0.75 \mathrm{~g}$ 이었다. 결론: 본 연구 결과로 뽕잎과 페퍼민트잎의 항산화 활성, tyrosinase 및 elastase 활성 억제 효능의 우수성을 규명하고, 최적 혼합 비율도 도출할 수 있었다. 이를 통해 inner beauty 소재 및 화장품 소재로써 이용가치가 높을 것으로 판단된다.

핵심어: RSM, 뽕잎, 페퍼민트잎, Tyrosinase 저해 활성, Elastase 저해 활성

\section{참고문헌}

곽윤진, 이대형, 김나미, 이종수. 각종 약용 식물로부터 피부노화 억제 관련 elastase 저해물질의 탐색 및 추출조건. 한국 약용작물학회지, 13: 213-216, 2005.

김계영, 박인식, 김성훈. 표고버섯 첨가가 복어육수의 항산화 활성에 미치는 영향. 한국식품영양학회지, $30: 742-748$, 2017.

송병준, 조정용, 마승진, 박경진, 박학재, 최경철, 하훈, 나환식. 쑥, 칡잎 그리고 다래잎의 채취시기 및 지역별 항산화,

Tyrosinase 저해 및 Elastase 저해 활성. 한국차학회지, 23: 65-73, 2017.

송화경, 권소영, 임윤숙, 김애정. 뽕잎 분말이 함유된 천연 팩 및 비누가 성인 남자의 피부 개선에 미치는 효과. 아시안뷰티

화장품학술지, 10: 911-919, 2012.

심봉섭, 이봉진. 미용기능식품 시장동향. 공업화학전망, 22: 23-37, 2019.

오세웅, 홍재훈. 옥수수수염과 뽕잎 추출물을 이용한 발효음료의 개발. 한국식품저장유통학회지, 28: 199-208, 2021.

유인서, 박지민, 김애정. 한국에서 다소비 되고 있는 식용꽃차의 생리활성. 아시안뷰티화장품학술지, 19: 289-301, 2021.

이미란, 부희정. 35종 에센셜 오일의 항산화, 항균 및 멜라닌 합성 저해 효과. 한국미용학회지, 23: 677-687, 2017.

이상재, 정지훈. 조선왕조실록을 통해 본 한국의 차문화. 대한예방한의학회지, 17: 17-28, 2013.

이아름, 김수현, 김수지, 김경조, 권오준, 최준영, 노성수. 최종당화산물 억제를 통한 桑葉의 항피부노화 효과. 대한본초학 회지, 32: 7-12, 2017.

이완주, 김애정, 김선여. 뽕잎의 기능성물질 탐색 및 효과 구명. 식품과학과 산업, $36: 2-14,2003$.

이재남, 김영삼. 이너뷰티 소재로서의 시계꽃 추출물의 활용 가능성. 한국응용과학기술학회지, 37: 1180-1189, 2020. 
이주연, 손효정. 여드름 피부에 효능 및 안전성을 가진 성분의 연구동향. 아시안뷰티화장품학술지, 16: 449-463, 2018. 정숙희, 구미정, 문희정, 유병철, 전만중, 이용환. Fucoidan의 멜라닌 합성과 tyrosinase 활성도 억제 효과. 생명과학회 지, 19: 75-80, 2009.

정연희, 한정순, 김애정. 로스팅한 연근과 우엉을 이용한 이너 뷰티 차의 항산화 활성과 품질 평가. 아시안뷰티화장품학술 지, 17: 235-245, 2019. 조기정, 이순옥. 전통 향약차(香藥茶) 고찰. 한국차학회지, $17: 1-7,2011$.

조종관, 천영순, 이기남. 조선시대 의학서 『醫林撮要』에 나타난 차의 효능 연구. 차문화산업학, 43: 51-74, 2019. 주민정, 권중호, 김현구. 용매에 따른 뽕잎과 오디의 생리활성 효과. 한국식품저장유통학회지, 16: 442-448, 2009. 함현미, 우관식, 이병원, 박지영, 심은영, 김병주, 이춘우, 김시주, 김욱한, 이준수, et al. 품종별 귀리 메탄올 추출물의 항 산화 성분 및 항산화 활성. 한국식품영양과학회지, 44: 1660-1665, 2015. 


\section{中文摘要}

\section{桑叶和薄荷叶最佳混合比例的皮肤美容效果}

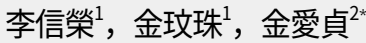

1京畿大学代替医疗学科, 首尔, 韩国

2京畿大学代替医疗大学院美容保健专业, 首尔, 韩国

目的: 本研究旨在确定桑叶和薄荷叶的最佳混合比例, 并评估其生物活性, 以确定所估算的比例是否适合用 于内在美容和化妆品成分。方法: 测定桑叶和薄荷叶的总多酚和黄酮含量、1,1-diphenyl-2-picrylhydrazyl (DPPH)、2,2'-azino-bis-3-ethylbenzothiazoline-6-sulfonic acid (ABTS)自由基清除活性、酪氨酸酶和弹性蛋 白酶抑制活性, 以优化桑叶和薄荷叶的混合比例。结果: 桑叶和薄荷叶混合物的总多酚含量高达46.58 mg TAE/ $\mathrm{g}$, 总黄酮含量高达45.54 mg QE/g，DPPH和ABTS自由基清除活性分别高达 $74.18 \%$ 和 $40.60 \%$ 。酪氨酸酶和弹 性蛋白酶抑制活性分别达到 $67.46 \%$ 和 $35.01 \%$ 。在兴趣部分，桑叶：薄荷混合比为 $1.49: 0.75(\mathrm{~g}: \mathrm{g})$ 时，可获得 最大的抗氧化和酪氨酸酶抑制活性。在实验部分, 桑叶与薄荷混合比例为 $1.79: 0.80(\mathrm{~g}: \mathrm{g})$ 时, 可获得最大的抗 氧化和酪氨酸酶抑制活性。此外, 当桑叶与薄荷的混合比为 $1.11: 0.75(\mathrm{~g}: \mathrm{g})$ 时, 可获得最大的抗氧化和弹性蛋 白酶抑制活性。结论: 本研究确定了桑叶和薄荷叶抗氧化活性、酪氨酸酶和弹性蛋白酶活性抑制效果的优越性, 以及桑叶和薄荷叶的最佳配比。根据我们的研究结果, 我们相信桑叶和薄荷叶在最佳的混合比例下, 将有相当 大的用途作为内在美和化妆品成分。

关键词: RSM, 桑叶, 薄荷叶, 酪氨酸酶抑制活性, 弹性蛋白酶抑制活性 
